\title{
IDENTIFIKASI PROSES Edemi EFEK DARI Smilax Sp
}

\author{
Maimuna Tualeka ${ }^{1}$, Aung Sumbono ${ }^{2}$, Sirojjuddin ${ }^{1}$ \\ ${ }^{1}$ Program Studi Pendidikan Biologi UNIMUDA Sorong \\ 2. Laboratorium KimiaUNIMUDA Sorong \\ Maimunatualeka96@gmail.com
}

\begin{abstract}
ABSTRAK
Tujuan penelitian untuk mengetahui proses edemi efek dari Smilax Sp. Metode penelitian eksperimen. Instrumen yang digunakan yakni observasi, dokumentasi, dan alat ukur. Tempat penelitian LaboratoriumMIPA UNIMUDASorong. Sampel yang digunakan yakni tumbuhan Smilax Sp dan Femur Galusgalus (Fgg), sampel Smilax Sp yang digunakan untuk masing-masing sampel Fgg sebanyak 20 gram, Fgg yang digunakan sebagai sampel berusia 2 bulan sebanyak 10. Hasil data dihitung menggunakan uji normalitas dan uji hipotesis yakni uji Mann-Whitney. Hasil penelitian menunjukkan bahwa penggunaan Smilax Sp mengakibatkan edemi. Hasil perhitungan semua data yakni empat data berdistribusi normal dan lima data berdistribusi tidak normal. Hasil uji Mann-Whitney pada semua sampel memiliki nilaiprobabilitas $0.000<0.05$, sehingga ada perbedaan antara sampel kontrol dan sampel eksperimen.Hasil penelitiandapatdisimpulkanbahwa: Smilax $S p$ memiliki aktivitas yang dapat menyebabkan edemi pada Fgg. Edemi diikuti dengan adanya kejadian pembesaran pori-pori kulit, warna kulit berubah dengan kode warna FFDD33, terpadat juga sedikit warna dengan kode warna FF6666 pada bagian atas kulit Fggyang terjadi karena kulit tersebut melepuh. Terdapat juga cairan seperti lendir berwarna FFFF99 yang keluar dari jaringan bawah kulit yaitu jaringan subkutan. Edemi pada penelitian ini hampir satu setengah kali lipat, dimana rata-rata pembengkakan massa pada Fgg yakni 55\%, lebar depan 33\%, lebar samping $35 \%$, dan diameter $38 \%$.
\end{abstract}

Kata Kunci: Edemi, Smilax, Fgg.

\begin{abstract}
The purpose of the study was to determine the process of edema effects of Smilax Sp. Experimental research method. The instruments used are observation, documentation, and measuring instruments. The place of research is Laboratory of MIPA UNIMUDA Sorong. The samples used were the Smilax Sp plant and the 2month-old Fgg of 10, the Smilax Sp sample used for each sample of Femur Galusgalus (Fgg) as much as 20 grams. Data results were calculated using the normality test and Mann-Whitney test. The results showed that the use of Smilax Sp resulted in edemias. Calculation data are four normal distribution data and five abnormal data. The results of the Mann-Whitney test in all samples were 0,000 <0.05. It was concluded that Smilax Sp has activity that can cause edemi in the Fgg, followed by an enlargement of the skin pores, skin color changes with the FFDD33 color code, densely colored with FF6666 color on the top of the skin due to blisters. There are also fluids such as FFFF99 colored mucus that comes out of subcutaneous tissue. Edemi is almost one and a half times higher, where the average mass swelling is 55\%, front width is 33\%, side width is 35\%, and diameters is $38 \%$.
\end{abstract}

Keywords:Edemi, Smilax, Fgg.

\section{PENDAHULUAN}

Indonesia adalah negara dengan keanekaragaman hayati yang memiliki keragaman spesies dan ekosistemnya yang sangat tinggi. Saat ini diperkirakan ada 42.584 spesies tumbuhan (39\% endemik) di Indonesia (1). Sumber daya alam hutan tropis di Indonesia melimpah. Hutan tropis di Indonesia mencakup sekitar 143 juta hektar, dan merupakan tanaman obat sekitar $80 \%$ dari seluruh dunia(2).Masyarakat Indonesia sudah lama mengenal dan menggunakan tanaman sebagai obat penanggulangan masalah kesehatan, termasuk di masyarakat pedesaan.

Penduduk lokal di daerah pedesaan memiliki pengetahuan yang baik tentang penggunaan tanaman dan mereka lebih menyukai tanaman obat karena ketersediaannya yang mudah dan terapi murah dibandingkan dengan obat-obatan mahal. Data dari Riset Kesehatan Dasar (Riskesdas) pada tahun 2013 menunjukkan 35,2\% masyarakat Indonesia masih mempertahankan dan menggunakan obat tradisional untuk pengobatan (3). Penggunaan tanaman obat secara historis dan terkini atau disebut juga dengan Etnobotani (4), sangat penting untuk konservasi budaya obat kuno. Etnobotani juga penting untuk konservasi sumber daya tanaman obat tradisional (5).

Sumber daya tanaman obat tradisional di Indonesia dikontribusi terbesar dari pulau Papua, lebih dari 50\% tanaman obat berada di wilayah Papua, dan sampai sekarang masih ada banyak yang tidak diketahui dan masih tersimpan di hutan-hutan di Papua, tetapi orang-orang yang tinggal di daerah Papua sudah menggunakan tanaman sebagai sumber kesehatan. Potensi tanaman sebagai sumber kesehatan 


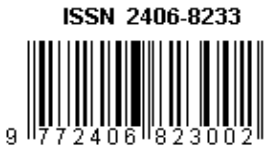

telah digunakan selama ratusan tahun oleh kelompok etnis yang tinggal di hutan sekitarnya dan pedesaan. Suku etnik memanfaatkan tanaman obat untuk pencegahan dan penyembuhan berbagai macam penyakit (6).

Tanaman yang digunakan sebagai obat untuk pencegahan dan penyembuhan adalah Laportea, $S p$, atau orang Papua menyebutnya daun gatal dan secara ilmiah dikenal dengan Laportea, Sp.(7), tanaman wati atau kava (Piper methysticum L; Piperaceae) (8), mahkota dewa $(\mathrm{MaDe})(9)$, sarang semut (MyrmecodiatuberosaJack./Rubiaceae) (10), sirih merah (Piper crocatumRuiz \&Pav./Piperaceae) (11)dan daun tiga jari.

Tanaman-tanaman tersebut dimanfaatkan oleh hampir semua suku di Papua. Tanaman tersebut tumbuh di dataran tinggi dan dataran rendah(12). Hasil penelitian di berbagai wilayah di Papua menunjukkan, bahwa pemanfaatan tumbuhan sebagai bahan obat tradisional di Papua cukup tinggi, dan setiap daerah mempunyai potensi yang berbeda(13).

Tetapi penggunaan obat tradisional perlu dilakukan kajian secara ilmiah guna pembuktian khasiat dan efek sampingnya. Beberapa penelitian tentang obat tradisional yang pernah dilakukan yakni: buah merah (Pandanus conoideus Lam.) khasiatnya untuk mengobati diabetes mellitus, jantung koroner, hipertensi bahkan HIV/AIDS (14), katuk (Sauropusandrogynus( L. ) Merr) untuk ibu menyusui dan sebagai anti oksidan (15)(16)(17), jahe (Zingiber officinalel Zingiberaceae) (18) telah digunakan untuk mengobati berbagai macam penyakit termasuk sakit perut, diare, mual, asma, gangguan pernafasan (19).

Salah satu pengobatan tradisional Papua yakni penggunaan tanaman daun tiga jari yang biasa digunakan untuk memperbesar alat kelamin pria oleh orang Papua. Pembesaran tersebut melalui proses pembengkakan (edemi).

Pembengkakan dapat terjadi akibat dari beberapa faktor seperti, karena gangguan keseimbangan cairan, atau pembuluh darah, neoplastik, penyakit granulomatosa menular dan inflamasi(20)(21). Selain itu,salah satunya bisa diakibatkan oleh zat atau komponen tertentu dari suatu tanaman. Tanaman yang mengandung suatu zat yang dapat mengakibatkan edemi yakni tanaman daun tiga jari (Smilax $S p$ ). Tetapi secara ilmiah penggunaan daun tiga jari sebagai obat tradisional tersebut belum diteliti, maka perlu dilakukan riset/kajian tentang penggunaan daun tiga jari sebagai obat tradisional. Penelitian ini bertujuan untuk mengetahui proses edemi efek dari Smilax $S p$.

\section{METODE PENELITIAN}

Pendekatan yang dipakai dalam penelitian ini adalah penelitian eksperimen. Penelitian eksperimen merupakan penelitian yang dilakukan dengan melakuka nmanipulasi yang bertujuan untuk mengetahui akibat manipulasi terhadap perilaku individu yang diamati.
BIOLEARNING JOURNAL

SN: 2406-8233; EISSN; 2406-8241 Volume 5 No. 2 Juli 2018

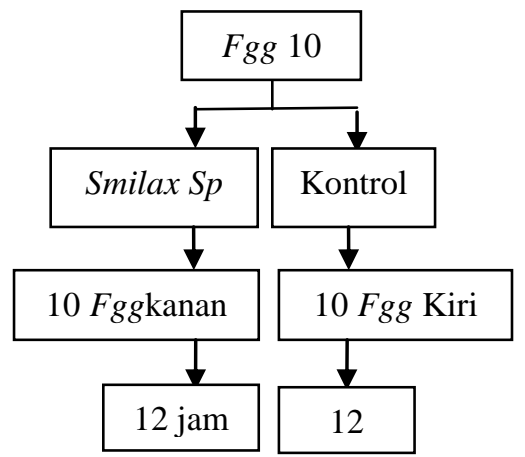

Gambar2-1 Skema penelitian.

Tempat pelaksanaan penelitian ini dilakukan di Laboratorium MIPA UNIMUDASorong dimulai sejak bulan Agustust ahun 2018.

Populasi dalam penelitian ini yakni tanaman obat dan hewan yang diperoleh di Kabupaten Sorong. Sampel dalam penelitian ini yakni tanaman Smilax $S p$ dan Fgg yang diperoleh dari Kabupaten Sorong. Tanaman Smilax Sp yang dipakai adalah daun tengah segar yang baru dipetik, Femur Galusgalus (Fgg) yang dipakai sebagai sampel adalah Fgg domesticus, yang berumur 2 bulan, dalam kondisi sehat, dan pakan terjamin.

Bahan yang digunakan dalam penelitian ini yaitu: daun Smilax Sp dari Kabupaten Sorong. Air bersih dan Fgg. Alat yang digunakan yaitu timbangan analitik, gunting/pisau, mortal, ember, spatula, kain kasa, kamera, penggarisdan cawan petri

Teknik dan instrumen pengumpulan data adalah observasi dan dokumentasi. Alat yang digunakan adalah: kamera, tabel warna, timbangan analitik

\section{PEMBAHASAN}

Perbandingan massa pada sampel Fgg eksperimen (kanan) terhadap kontrol (kiri) setelah diberi perlakuan selama 12 jam diperoleh data, ditampilkan pada Gambar 3-1.

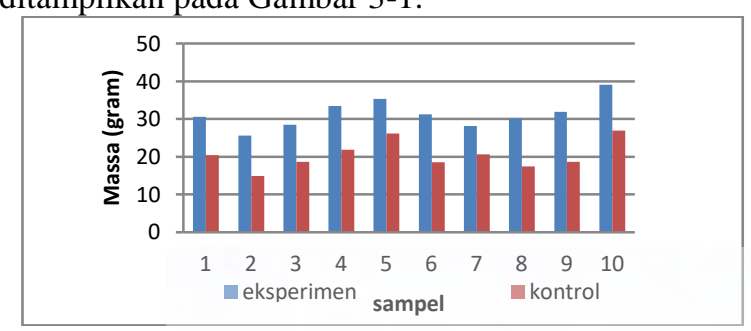

Gambar 3-1Grafik data massa sampel FK dan FE

Massa rata-rata Fgg pada sampel eksperimen (FE) dan kontrol (FK) diperoleh data yakni, pada Gambar 3-2.

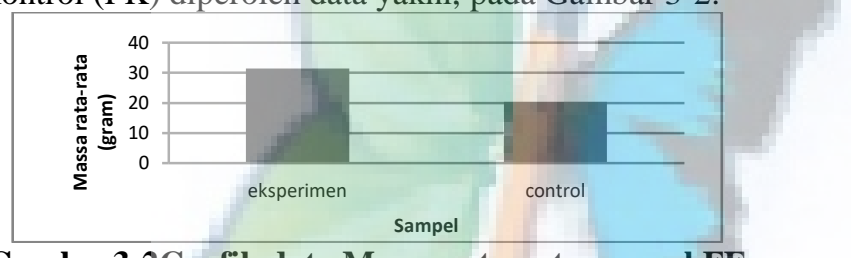

Gambar3-2Grafik data Massa rata-rata sampel FE dan FK

Selisih massa FK dan FE diperoleh data yakni pada Gambar 3-3. 

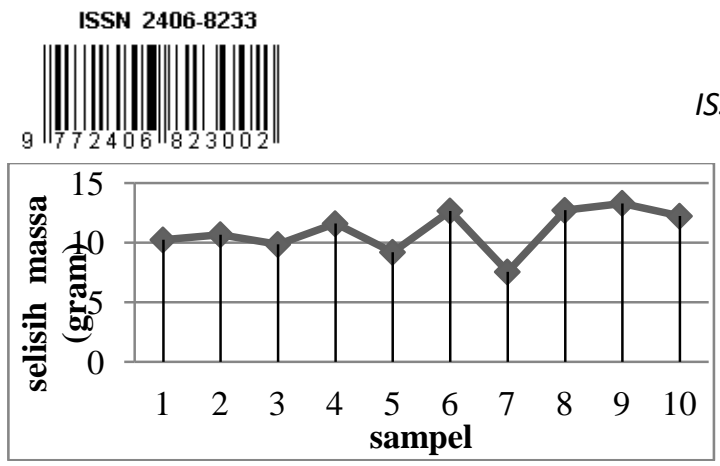

Gambar3-3 Grafik data selisih massaFE dan FK

Data lebar bagian depan pada FE ditampilkan dalam bentuk grafik pada Gambar 3-4,

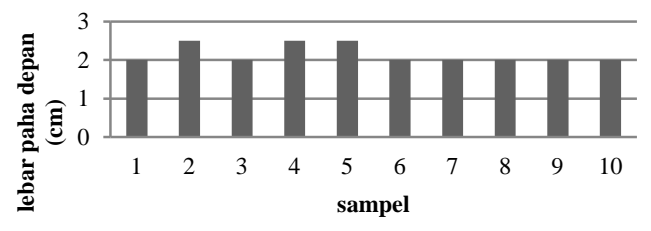

Gambar3-4 Grafik data lebar depan sampel FE

Data lebar bagian samping pada FE ditampilkan dalam bentuk grafik pada Gambar 3-5.

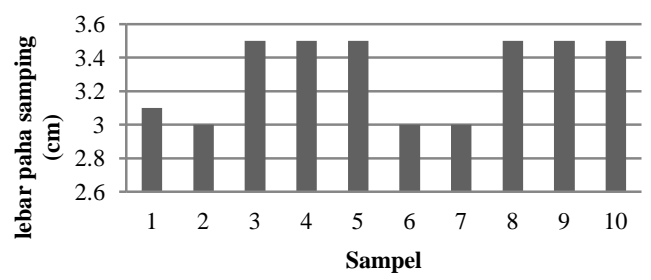

Gambar3-5 Grafik data lebar samping sampel FE

Data diameter pada FE ditampilkan dalm bentuk grafik pada gambar 3-6.

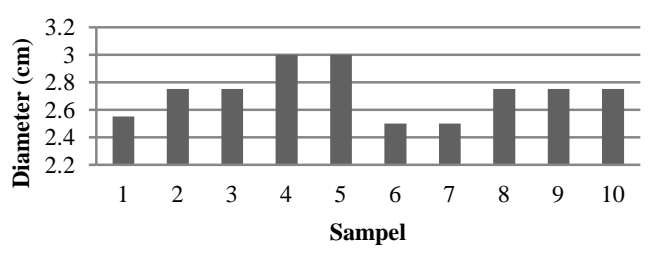

Gambar3-6 Grafik data diameter pada sampel FE

Data lebar bagian depan FK ditampilkan dalam bentuk grafik pada Gambar 3-7.

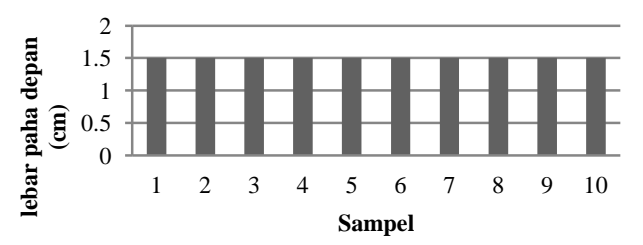

Gambar3-7 Grafik data lebar depan sampel FK

Data lebar bagian samping pada FK ditampilkan dalam bentuk grafik pada Gambar 3-8.
BIOLEARNING JOURNAL

ISSN: 2406-8233; EISSN; 2406-8241 Volume 5 No. 2 Juli 2018

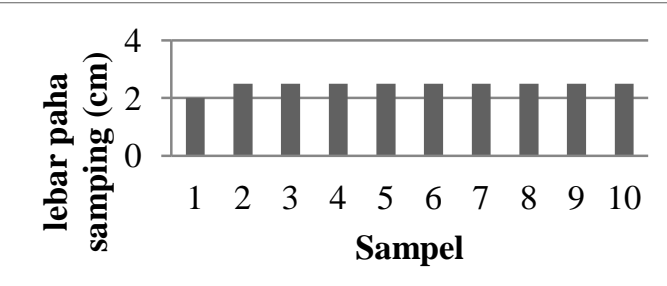

Gambar3-8 Grafik data lebar samping pada sampelFK

Data diameter pada sampel kontrol ditampilkan dalam bentuk grafik pada Gambar 3-9.

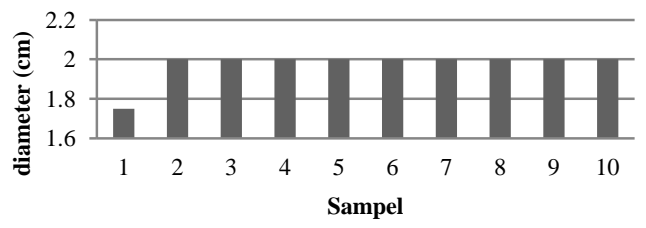

Gambar3-9 Grafik data diameter pada sampel FK

Data selisih massa pada FK dan eksperimen ditampilkan dalam bentuk grafik pada Gambar 3-10.

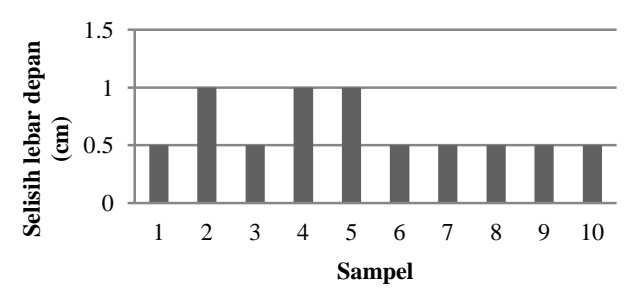

Gambar3-10 Grafik data selisih lebar depan

Data selisih lebar samping pada FK dan FE ditampilkan dalam bentuk grafik pada Gambar 3-11.

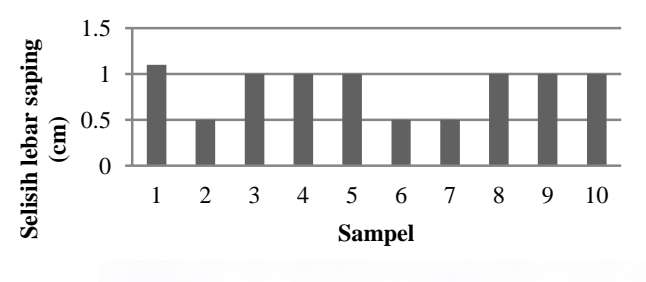

Gambar3-11 Grafik data selisih lebar samping

Data selisih diameter pada FK dan FE ditampilkan dalam bentuk grafik pada Gambar 3-12.

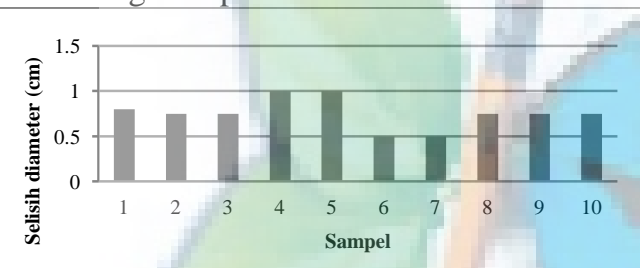

Gambar3-12 Grafik data selisih diameter Data persentase massa FE dan FK ditampilkan pada Gambar 3-13. 


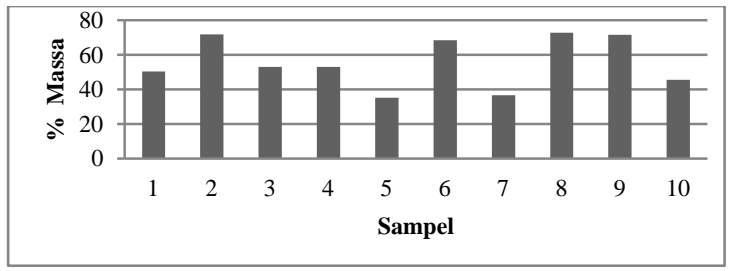

Gambar3-13 Grafik data persentasemassaFE dan FK

Data persentase lebar depan FE dan FK ditampilkan pada Gambar 3-14.

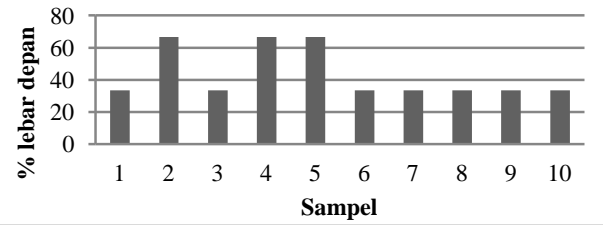

Gambar3-14 Grafik data persentase lebar depan

Data persentase lebar depan FE dan FK ditampilkan pada Gambar 3-15.
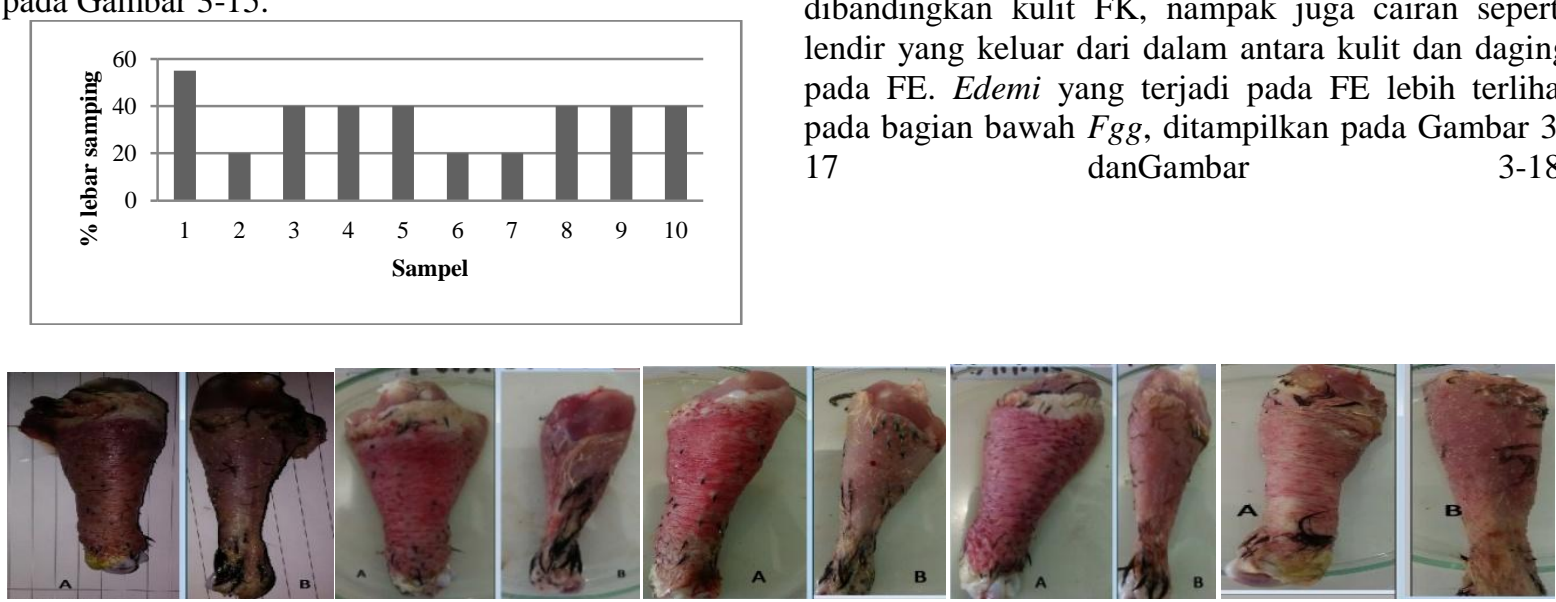

Gambar3-17 Sampel 1 sampai 5: eksperimen (A), kontrol (B)

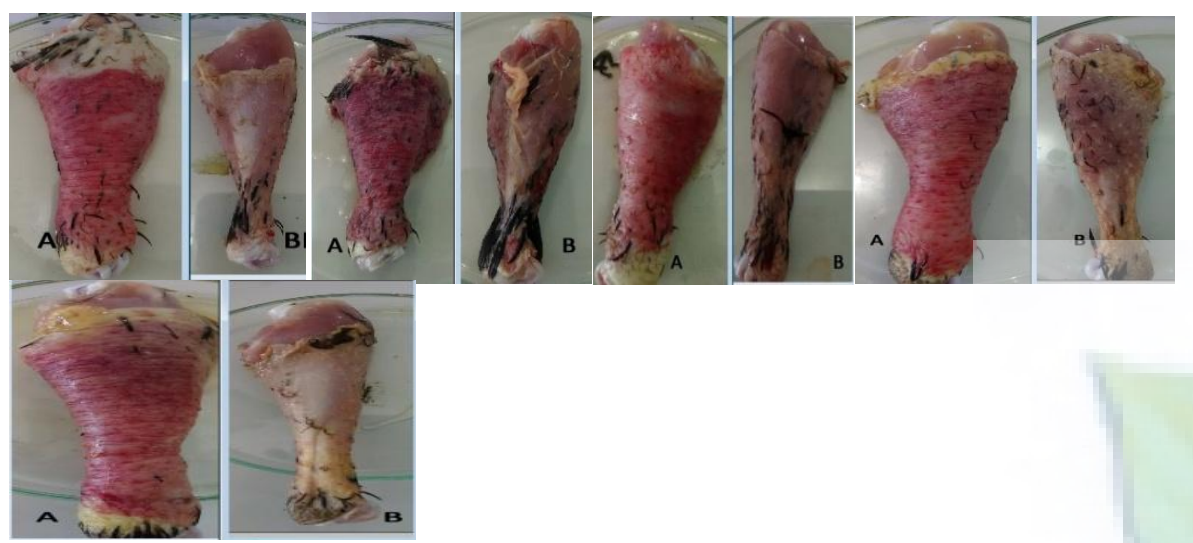

Gambar3-18 Sampel 7 dan 8: eksperimen (A), kontrol (B)

Berdasarkan hasil perhitungan uji normalitas pada sampel eksperimen menunjukkan masing-masing bahwa berdasarkan perumusan saphiro wilk yakni untuk berat memiliki nilai sig sebesar 0.894, panjang memiliki nilai sig 0.683, lebar depan 0.000, lebar samping 0.000 , diameter 0.065 .
Padaperhitungan Shapiro-Wilk terdapat dua variabel yang nilai $\alpha>0.05$, dan tiga variabelnya < 0.05. Maka penyebaran data yang dihasilkan dari sampel eksperimen adalah dua variabel berdistribusi normal dan tiga variabel berdistribusi tidak normal

.Berdasarkan hasil perhitungan uji normalitas berdasarkan perumusan saphiro wilk pada sampel 
kontrol menunjukkan masing-masing bahwa yakni untuk berat memiliki nilai sig sebesar 0.369 , panjang memiliki nilai sig 0.683 , lebar samping 0.000 , diameter 0.000 .

Padaperhitungan Shapiro-Wilk terdapat dua variabel yang nilai $\alpha>0.05$, dan 2 variabelnya $<0.05$, sedangkan pada lebar samping memiliki nilai yang konstan. Maka penyebaran data yang dihasilkandari sampel kontrol adalah dua variabel berdistribusi normal dan 2 variabel berdistribusi tidak normal

Hasil pembengkakan pada tampilan luar diperoleh gambaran bahwa pembengkakan terjadi dengan ditandai adanya bercak merah pada kulit. Hasil pembekakan ditampikan pada Gambar 3-22.

Pada tampilan (A) selain terjadi pembengkakan juga terdapat warna putih (1a), kemudian terdapat bintik merah (2a), terjadi pembesaran pori-pori (3a). Tampilan (B) kulit menjadi lebih tebal (1b), dan terdapat kerutan (2b). Tampilan (C) daging pada sampel lebih tebal (1c).

Uji hipotesis dilakukan uji Mann-Whitney karena hasil uji normalitas data yang ada perlakuan dinyatakan tidak normal dan tanpa perlakuan dinyatakan normal.

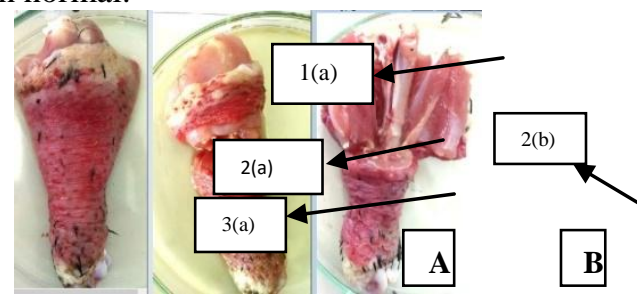

Gambar3-19 Sampel eksperimen: utuh (A), potongan melintang $(B)$, potongan membujur $(C)$

Berdasarkan hasil perhitungan pada baris Asymp Sig terlihat bahwa nilai probabilitas 0.000. Dari hasil perhitungan tersebut maka disimpulkan bahwa berat pada sampel eksperimen dan sampel kontrol tidak sama.

Berdasarkan hasil perhitungan pada baris Asymp Sig terlihat bahwa nilai probabilitas 0.000. Dari hasil perhitungan tersebut maka disimpulkan bahwa diameter pada sampel eksperimen dan sampel kontrol tidak sama.

Berdasarkan hasil perhitungan pada baris Asymp Sig terlihat bahwa nilai probabilitas 0.000. Dari hasil perhitungan tersebut maka disimpulkan bahwa lebar depan pada sampel eksperimen dan sampel kontrol tidak sama.

Berdasarkan hasil perhitungan pada baris Asymp Sig terlihat bahwa nilai probabilitas 0.000 . Dari hasil perhitungan tersebut maka disimpulkan bahwa lebar depan pada sampel FE dan sampel FK tidak sama.

Uji hipotesis yang diterima adalah ada aktivitas daun SmilaxSp. Hal ini dibuktikan dengan hasil akhir perhitungan pada uji Mann-Whitney yang menunjukkan bahwa berdasarkan hasil perhitungan pada baris Asymp Sig terlihat bahwa nilai probabilitas 0.000. Dengan demikian hasil penelitian menunjukkan bahwa penggunaan Smilax Sp mengakibatkan edemi.
Edemi terhadap Fgg dampak dari aktivitas daun Smilax Sp, terbukti dimana sampel eksperimen memiliki massa, lebar dan diameter lebih besar dari pada sampel kontrol. Diameter sampel FE dan FK menunjukkan perbedaan. Perbedaan tersebut yakni pada sampel eksperimen memiliki diameter lebih besar karena mengalami edemi akibat aktivitas dari Smilax Sp.

Perbandingan massa sampel FE dan FK hasil penelitian menunjukkan perbedaan. Perbedaan tersebut yakni pada sampel eksperimen memiliki massa lebih besar karenaterjadi edemi. Jenis edemi yang terjadi adalah Angioedema. Angioedema adalah edemi berbeda dengan gatal-gatal dimana edemi disebabkan di bawah kulit dan bukan di permukaan kulit(23).

Lebar Fgg pada sampel FE dan FK hasil penelitian menunjukkan perbedaan. Perbedaan tersebut yakni pada FE lebih besar dibanding yang F, ini terjadi akibat adanya edemi. Edemi terjadi karena banyaknya cairan darah yang dikirim ke lokasi cedera dan merembes keluar dari kapiler menuju ruang antar sel(24).Padapenelitianini terjadiedemi akibat dari aktivitas Smilax $S p$, karena Smilax $S p$ mengandung zat y 1 (b) henyebabkan inflamasi sehingga terjadi Inflamasi merupakan suatu respon protektif normal terhadap luka jaringan yang disebabkan oleh trauma fisik, zat kimia yang merusak, atau zat-zat mikrobiologit (25). Respon inflamasi ditandai oleh kondisi beru C.ubor (kemerahan), kalor (panas), dolor (nyeri), tumor (edemi) dan gangguan fungsi (26).

Tumbuhan marga Smilax mempunyai kandungan steroidal saponin yang melimpah (27) dan (28). Steroidal saponin mempunyai beberapa aktivitas biologi salah satunya sebagai anti-inflamasi (29). Penelitian Sparg berbeda dengan hasil penelitian ini, dimana terjadi inflamasi pada sampel Fgg yang dibungkus menggunakan Smilax $S p$. Perbedaan tersebut terjadi karena spesies Smilax yang digunakan Sparg adalah Smilax Scobinicaullis, sedangkan pada penelitian ini menggunakan Smilax Sp. Ini membuktikan bahwa Smilax $S p$ yang digunakan dalam penelitian ini memiliki senyawa lain selain senyawa yang telah ditemukan dalam Smilax Scobinicaullis.

Edemi pada penelitian ini hampir satu setengah kali lipat, dimana rata-rata pembengkakan massa pada Fgg yakni 55\%, lebar depan 33\%, lebar samping 35\%, dan diameter $38 \%$. Persentase edemi mirip dengan besarnya persentase edemi yang ditemui pada sebagian besar wanita hamil, dimana edemi yang dialami hingga mencapai $67 \%$ dan bagian tubuh yang paling sering terjadi edemi yaitu pada tungkai bawah kaki yakni sebesar 49\%(30).

Edemi diikuti dengan adanya kejadian pembesaran pori-pori kulit. Penyebab utama terjadinya pembesaran pori-pori wajah, yaitu ekskresi sebum yang tinggi, penurunan elastisitas di sekitar pori-pori, dan peningkatan volume folikel rambut(31). 
Edemi diikuti warna kulit berubah dengan kode warna FFDD33, perubahan warna kulit terjadi karena pembuluh darah melebar (vasodilatasi). Pelebaran pembuluh darah inilah yang mengakibatkan warna kulit terlihat lebih merah (rubor)(24). Terpadat juga sedikit warna dengan kode warna FF6666 pada bagian atas kulit Fgg yang terjadi karena kulit tersebut melepuh. Terlihat juga cairan seperti lendir berwarna FFFF99 yang keluar dari jaringan bawah kulit yaitu jaringan subkutan, jaringan subkutan adalah lapisan lemak dengan ketebalan beberapa mili meter terletak di bawah dermis (32). Cairan tersebut disebabkan karena akumulasi pelepasan cairan dari pembuluh darah kecil (kapiler) atau ruang interstisial ke jaringan di dekatnya, penumpukan cairan dapat menyebabkan pembengkakan karena alasan seperti tekanan di dalam pembuluh darah, setelah pengangkatan kelenjar getah bening, peradangan, retensi air, tekanan hidrostatik, tekanan onkotik jaringan (interstisial). Kerusakan kapiler atau peningkatan tekanan baik oleh cedera atau peradangan menyebabkan pembengkakan bagianbagian tubuh (33).

\section{KESIMPULAN}

Hasil penelitiandapatdisimpulkanbahwa:

1 Smilax $S p$ memiliki aktivitas yang dapat menyebabkan edemi pada Fgg.

2 Edemi diikuti dengan adanya kejadian pembesaran pori-pori kulit, warna kulit berubah dengan kode warna FFDD33, terpadat juga sedikit warna dengan kode warna FF6666 pada bagian atas kulit Fggyang terjadi karena kulit tersebut melepuh.

3 Terdapat juga cairan seperti lendir berwarna FFFF99 yang keluar dari jaringan bawah kulit yaitu jaringan subkutan.

Edemi pada penelitian ini hampir satu setengah kali lipat, dimana rata-rata pembengkakan massa pada Fgg yakni $55 \%$, lebar depan 33\%, lebar samping 35\%, dan diameter $38 \%$.

\section{DAFTAR PUSTAKA}

1. Widjaja, et al.Kekinian keanekaragaman hayati Indonesia 2014. Jakarta : LIPI Press, 2014.

2. Balick, et al.Medicinal resources of the tropical forest:. New York: Columbia University Press:, 1996.

3. Studi Etnobotani Pengobatan Tradisional untuk Perawatan Wanita di Masyarakat Keraton Surakarta Hadiningrat. Shanthi, et al. 2014, Biosaintifika: Journal of Biology \& Biology Education, hal. 61-69.

4. Utilization of weed species as source of traditional medicines in central Kenya. Njoroge, et al. 2004, Indigenous Uses and Pharmacological Activity of Traditional Medicinal Plants in Mount Taibai, China, hal. 71-87.

5. Plant biodiversity and ethnobotany of Borana pastoralists in southern Oromia, Ethiopia.
Gemedo-Dalle, et al. 2005, Economic Botany, hal. 43-65.

6. Etn Of Armakologi Plants Ants Nest Papua (Hydnophytum Formicarum) On Skouw Tribe Of Papua . Hadju V et al. 2016, International Journal of Research In Medical and Health Sciences, hal. 26-32.

7. John, R.Common Forest Trees of Irian Jaya Papua Indonesia. Royal Botancal Garden. Inggris : s.n., 1997.

8. The efforts to conserve of wati (Piper methysticum) medicinal plants. Nova, KN. 2009, Wati (Piper methysticum) medicinal plant: The ethnobiological and ethnomedicinal values of the Marind tribe in Merauke, Papua, Indonesia, hal. 27-30.

9. Harmanto, N.Mahkota Dewa: God Medicine. Jakarta, Indonesia. : PT Agromedia Pustaka, 2001.

10. Traditional Medicine Journal. Efendi \& Hertiani. 2013, A Mini Review Of Indonesian Medicinal Plants For Vulvovaginal Candidiasis .

11. Biomedika. Candrasari, et al. 2012, A Mini Review Of Indonesian Medicinal Plants For Vulvovaginal Candidiasis.

12. Phytochemical and Physicochemical Analysis of the Leaves of Laportea aestuans (Linn.) Chew and Laportea ovalifolia (Schumach.) Chew (Male Female). Asian Journal of Plant science and reseacrh. Essiett, et al. 2011, Genetic Analysis of Itchy Leaves (Laportea, sp) in Papua for Herbal Medicinal Products as Development of Studying Economics Value, hal. 35-42.

13. Sada \& Rosye.Keragaman Tumbuhan Obat Tradisional di Kampung Nansfori Distrik Supiori Utara, Kabupaten Supiori-Papua. Jayapura : s.n., 2010.

14. Buah Merah: potensi dan manfaatnya sebagai antioksidan. [Red Fruit (Pandanus conoideus): potential and benefits in terms of antioxidants]. Palupi \& Martosupomo. 2009, Jurnal Tumbuhan Obat Indonesia, hal. 42-48.

15. Aktivitas antioksidan senyawa flavonoid dari daun katuk (Sauropus androgunus (L.) Merr.). Jurnal Biologi Sumatera. Zuhra, et al. 2008, Local Knowledge of Katuk (Sauropus androgynus ( L. ) Merr) in East Java, Indonesia, hal. 7-10.

16. Free radical scavenging activity of multi-vitamin plant (Sauropus androgynus L. Merr). Nahak, \& Sahu. 2010, Local Knowledge of Katuk (Sauropus androgynus ( L. ) Merr) in East Java, Indonesia, hal. 6-14.

17. Yahdillah.Sayuran Asli Indonesia kandung antioksidan tinggi. Jakarta : s.n., 2009. 
18. Jurnal Biologi Universitas Andalas. Sari, et al. 26. Uji Aktivitas Antiinflamasi Ekstrak Etanol Daun 2013, A Mini Review Of Indonesian Medicinal Plants For Vulvovaginal Candidiasis .

19. Ginger-A herbal medicinal product with broad anti-inflammatory actions. J. Med. Food. Grzanna, et al. 2005, Chemical composition and antioxidant properties of ginger root (Zingiber officinale), hal. 125-132.

20. Erysipelas and elephantiasis of the scrotum. Surgical and drug therapy. Geyer, et al. 1995, Chronic Idiopathic Penile Edema: Three Cases and a Review of the Literature, hal. 59-61.

21. Granulomatous lymphangitis of the scrotum and penis. Report of a case and review of the literature of genital swelling with sarcoidal granulomatous inflammation. Murphy, et al. 2001, Chronic Idiopathic Penile Edema: Three Cases and a Review of the Literature, hal. 419-24.

22. Sekaran, U.Research Methods for Business: A Skill Building Approach. New York : s.n., 2003.

23. A Review on Edema. Aslesha, E. 2016, Research and Reviews: Journal of Pharmaceutical Analysis, hal. 63-70.

24. Faktor Timbulnya Cedera Olahraga. Setiawan, A. 2011, Jurnal Media Ilmu Keolahragaan Indonesia Volume 1., hal. 94-98.

Pisang Ambon (Musa Paradisiaca L.) Terhadap Tikus Putih (Rattus Norvegicus L.) Yang Diinduksi Karagenan . Sukmawati et al. 2015, GALENIKA Journal of Pharmacy Vol. 1 (2), hal. 126-132.

27. Advance in Biology and Chemistry of the Genus Smilax. Liu HQ et al. 2001, Natutal Product Research and Development, hal. 90-93.

28. Steroidal Saponins from the Roots of Smilax aspera subsp. Belhouchet $\mathbf{Z}$ et al. 2008, mauritanica. Chemical and Pharmaceutical Bulletin, hal. 1324-1327.

29. Biological Activities and Distribution of Plant Saponins. Sparg SG et al. 2004, Journal of Ethnopharmacology, hal. 219-43.

30. Frequency of Lower Extremity Edema during Third Trimester of Pregnancy. Tanveer, F et al. 2017, hal. 41-43.

31. Facial Pores: Definisi, Penyebab, dan Pilihan Perawatan. Lee SJ et al. 2016, Dermatol surg.

32. The mechanical behavior of skin: Structures and models for the finite element analysis. Benítez JM, \& Montáns FJ. 2017, Glycative stress and anti-aging: 7. Glycative stress and skin aging, hal. 75-107.

33. Edema: a silent but important factor. Villeco, JP. 2012, J Hand Ther, hal. 153-162.

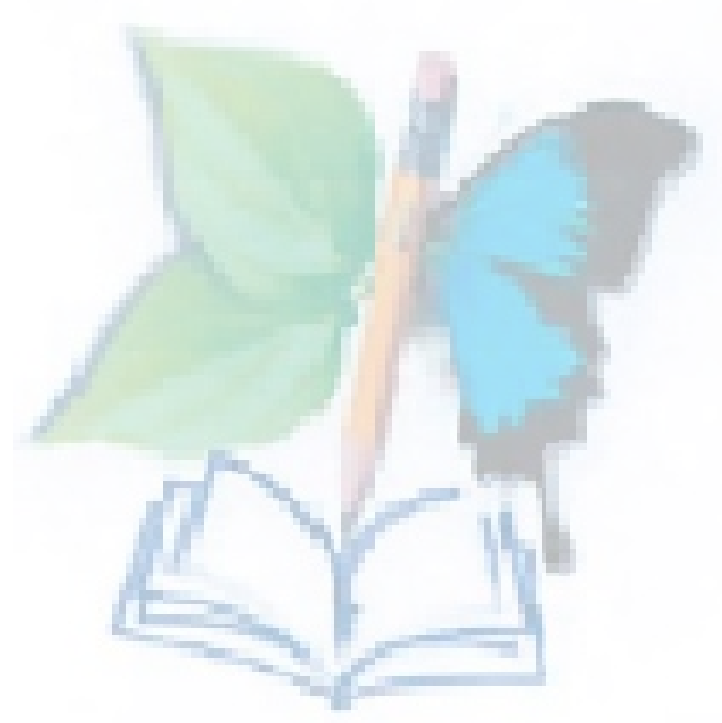

